FINANCIAL: Jurnal Akuntansi

Published by Program Studi Akuntansi STIE Sultan Agung

Volume 7-Nomor 1, Juni 2021, (Hlm 97-104)

ISSN-P: 2502-4574, ISSN-E: 2686-2581

Available online at: https://financial.ac.id/index.php/financiaI

\title{
ANALISIS FAKTOR-FAKTOR YANG MEMPENGARUHI KUALITAS LABA PADA PERUSAHAAN INDEX LQ 45 PERIODE 2015-2019
}

\author{
Elly Susanti $^{1)^{*}}$, Khairul Azwar ${ }^{2)}$, Astuti ${ }^{3)}$ \\ ${ }^{1,2,3}$ Program Studi Akuntansi, Sekolah Tinggi Ilmu Ekonomi Sultan Agung, Jalan Surabaya No.19, \\ Pematangsiantar, Sumatera Utara, 21118, Indonesia \\ E-mail: ${ }^{1}$ susantielly82@gmail.com, ${ }^{2}$ khairulazwar206@gmail.com, ${ }^{3}$ astutisemsi91@gmail.com
}

\begin{abstract}
Abstrak
Investor memerlukan informasi laba agar dapat menilai kinerja keuangan perusahaan di masa yang lalu guna memprediksi kinerja keuangan perusahaan di masa depan. Oleh karena itu diperlukan laba yang berkualitas yang dapat mencerminkan kinerja keuangan perusahaan. Penelitian ini bertujuan untuk mengetahui dan menganalisis faktor faktor (CR, Size, IOS dan DPR) yang mempengaruhi kualitas laba. Penelitian ini dilakukan pada perusahaan Index LQ 45 selama periode 2015-2019, pengambilan sampel dilakukan secara purposive sampling sehingga yang menjadi sampel dalam penelitian ini sebanyak 18 perusahaan. Data dikumpulkan dengan menggunakan teknik dokumentasi, sedangkan analisis data menggunakan uji asumsi klasik dan pengujian hipotesis. Dari penelitian ini diperoleh hasil bahwa CR, Size, DAR, IOS dan DPR memiliki pengaruh yang signifikan secara simultan. Secara parsial CR, Size, IOS dan DPR memiliki pengaruh positif signifikan terhadap kualitas laba sedangkan DAR memiliki pengaruh negatif tidak signifikan terhadap kualitas laba.
\end{abstract}

Kata kunci: Kualitas Laba, CR, Size, DAR, IOS dan DPR

\section{FACTORS AFFECTING THE QUALITY OF PROFIT INDEX LQ 45 COMPANIES PERIOD 2015-2019}

\begin{abstract}
Investors need profit information in order to assess the company's past financial performance in order to predict the company's future financial performance. Therefore, it is necessary to have a quality of profit that can reflect the company's financial performance. This study aims to determine and analyze the factors (CR, Size, IOS and $D P R)$ that affect quality of profit. This research was conducted at the $L Q 45$ Index company during the 2015 2019 period, the sampling was carried out by purposive sampling so that the samples in this research were 18 companies. Data were collected using documentation techniques, while data analysis used classical assumption and hypothesis tests. From this research, it is found that CR, Size, DAR, IOS and DPR have significant effects simultaneously. Partially CR, Size, IOS and DPR have positive significant effect on quality of profit while DAR has negative insignificant effect on quality of profit.
\end{abstract}

Keywords: Quality of Profit, CR, Size, DAR, IOS and DPR.

Article History: Received: 05 Mei 2021 Revised: 16 Mei 2021 Accepted: 24 Mei 2021 


\section{PENDAHULUAN}

Laporan keuangan memuat informasi laba perusahaan yang dibutuhkan oleh pihak yang berkepentingan untuk menilai kemampuan perusahaan dalam meningkatkan kinerja keuangannya. Dengan adanya informasi tersebut maka perusahaan dapat mengetahui posisi perkembangan usahanya. Oleh sebab itu, laba menjadi pusat perhatian bagi seluruh pihak, karena laba merupakan salah satu aspek yang sangat penting dalam hal pengambilan keputusan serta menafsirkan risiko investasi di masa mendatang. Jika laba memuat sebuah informasi yang bisa diandalkan, maka para penanam modal dengan cepat menanggapi pengumuman laba tersebut yang berarti bahwa informasi laba yang diberikan berkualitas (Ginting, 2013).

Terdapat beberapa permasalahan pada saham-saham perusahaan yang paling likuid yang termasuk dalam Indeks LQ 45 di Bursa Efek Indonesia antara lain pertumbuhan laba perusahaan mengalami penurunan dari tahun ke tahun yaitu sebesar 1,14\% menjadi Rp. 41,39 triliun pada kuartal I/2016. Penyebabnya karena perusahaan yang bergabung di indeks LQ 45 telah membukukan kinerja keuangan kuartal I/2016 sebesar 88\%. Sedangkan masih terdapat 5 emiten lainnya yang tidak menyajikan laporan keuangan interim unaudited (Sukirno, 2015). Berikutnya sederetan emiten membukukan pelemahan kinerja keuangan pada perusahaan Indeks LQ 45 di kuartal III tahun 2019. Ini penyebabnya adalah 38 perusahaan dengan kapitalisasi besar pada LQ45 mengalami pelemahan pertumbuhan laba. Kondisi ini sejalan dengan pertumbuhan pendapatan perusahaan yang lambat (Thertina, 2019).

Kualitas laba dipengaruhi oleh beberapa faktor antara lain CR (Current Ratio), Size, DAR (Debt To Asset Ratio),
IOS (Investment Opportunity Set) dan DPR (Dividend Payout Ratio). Beberapa penelitian pernah membahas mengenai faktor faktor yang mempengaruhi kualitas laba antara lain (Sukmawati et al., 2014) dengan hasil menunjukkan bahwa $\mathrm{CR}$ berpengaruh terhadap Kualitas laba sedangkan Ukuran perusahaan dan ROA tidak berpengaruh terhadap kualitas laba, (Helina \& Permanasari, 2017) dengan hasil menunjukkan bahwa Ukuran perusahaan dan cash holding berpengaruh terhadap kualitas laba sedangkan keputusan investasi, ukuran perusahaan dan current ratio tidak berpengaruh terhadap kualitas laba, (Laoli \& Herawaty, 2019) menunjukkan bahwa profitabilitas, leverage dan ukuran perusahaan berpengaruh negative terhadap kualitas laba, (Fauziah \& Kusumadewi, 2019) dengan hasil menunjukkan bahwa deviden berpengaruh terhadap kualitas laba, (Herninta \& Ginting, 2020) dengan hasil penelitian menunjukkan bahwa leverage, profitabilitas dan ukuran perusahaan berpengaruh terhadap kualitas laba sedangkan likuditas tidak berpengaruh terhadap kualitas laba dan (Maysitha et al., 2021) dengan hasil menunjukkan bahwa IOS dan likuiditas berpengaruh positif terhadap kualitas laba sedangkan leverage berpengaruh negatif terhadap kualitas laba. Hal inilah yang melatarbelakangi peneliti untuk meneliti kembali faktor-faktor yang dapat mempengaruhi kualitas laba suatu perusahaan.

Tujuan dilakukannya penelitian ini yaitu untuk menganalisis faktor-faktor yang dapat mempengaruhi kualitas laba secara simultan dan parsial. 


\section{LANDASAN TEORI}

\section{Signaling Theory}

Teori sinyal atau signaling theory merupakan teori yang menjabarkan kondisi perusahaan untuk mempublikasikan informasi keuangan kepada pihak pihak yang membutuhkan khususnya mengenai kinerja perusahaan. Dengan adanya informasi tersebut maka akan memberikan sinyal bagi para investor mengenai reaksi pasar yang terjadi. Dengan demikian, teori sinyal ini menekankan bahwa perusahaan lebih cenderung memiliki informasi yang lebih komprehensif sehingga investor dapat melakukan investasi berupa dana di perusahaan yang mereka inginkan (Herninta \& Ginting, 2020).

\section{Kualitas Laba}

Kualitas laba merupakan penilaian keuntungan yang diperoleh perusahaan secara berkelanjutan sehingga dapat mencerminkan keadaan sebenarnya dari keuangan perusahaan. Kualitas laba juga merupakan indikator apakah laba yang diperoleh perusahaan sama dengan rencana sebelumnya (Herninta \& Ginting, 2020). Laba dengan kualitas yang baik ialah laba yang berguna untuk pengambilan keputusan dengan karakteristiknya berupa relevansi, reliabilitas, komparabilitas, atau konsistensi. (Helina \& Permanasari, 2017).

\section{Current Ratio (CR)}

CR ialah rasio yang menunjukkan apakah suatu perusahaan memiliki kemampuan untuk memenuhi segala hutang yang segera jatuh tempo dengan mempergunakan aset lancar perusahaan saat ini (Sukamulja, 2017). Semakin tinggi kemampuan perusahaan dalam membayar kewajibannya maka perusahaan akan dinilai likuid sehingga dianggap memiliki kinerja Copyright (C) 2021, FINANCIAL: Jurnal Akuntansi keuangan baik. Keadaan ini dapat menumbuhkan daya tarik investor dalam berinvestasi di perusahaan. Dengan kata lain bahwa dengan semakin tingginya $\mathrm{CR}$ menyebabkan semakin tinggi pula kualitas laba suatu perusahaan. Pendapat di atas sesuai penelitian (Herninta \& Ginting, 2020) dan (Sukmawati et al., 2014) dengan hasil bahwa likuiditas memiliki pengaruh yang positif signifikan terhadap kualitas laba.

$\mathrm{H}_{1}$ : $\mathrm{CR}$ berpengaruh positif signifikan terhadap Kualitas laba

\section{Ukuran Perusahaan (Size)}

Ukuran perusahaan merupakan indikator seberapa besar suatu perusahaan yang dapat dijadikan sebagai bahan pertimbangan oleh para investor terkait keputusan dalam berinvestasi pada perusahaan tersebut (Samrotun, 2015). Ukuran perusahaan yang semakin besar berdampak pada semakin tingginya usaha perusahaan untuk dapat meningkatkan kinerja sehingga dapat mengurangi praktik manipulasi laba (Sukmawati et al., 2014). Pendapat di atas sesuai dengan penelitian (Sukmawati et al., 2014) dan (Herninta \& Ginting, 2020).

$\mathrm{H}_{2}$ : Size berpengaruh positif signifikan terhadap kualitas laba

\section{Debt To Asset Ratio (DAR)}

DAR ialah rasio yang menunjukkan apakah suatu perusahaan memiliki kemampuan dalam melunasi seluruh kewajibannya dengan mempergunakan aset sebagai jaminan (Silitonga et al., 2020). Kecilnya nilai rasio ini mempengaruhi anggapan investor bahwa perusahaan akan mampu membayar dividen perusahaan yang telah jatuh tempo. Pendapat ini sesuai dengan penelitian (Maysitha et al., 2021) dan (Laoli \& Herawaty, 2019). 
$\mathrm{H}_{3}$ : DAR berpengaruh negatif signifikan terhadap kualitas laba

\section{Investment Opportunity Set (IOS)}

IOS digunakan sebagai tolak ukur pertumbuhan suatu perusahaan pada masa yang akan datang, sehingga IOS sangat dipengaruhi oleh pengeluaran perusahaan di masa depan yang ditetapkan oleh manajemen guna mencari peluang bagi perusahaan untuk berkembang (Warianto \& Rusiti, 2016). Emiten dengan IOS yang tinggi biasanya akan dipandang baik oleh investor dikarenakan memiliki nilai tambah untuk peningkatan keuntungan, sehingga meningkatnya IOS tersebut maka keuntungan akan meningkat juga dikarenakan semakin banyak investor yang berinvestasi di perusahaan dengan mengharapkan keuntungan dengan jumlah yang besar di kemudian hari. Pendapat ini sejalan dengan penelitian yang dilakukan oleh (Wulansari, 2013), (Warianto \& Rusiti, 2016) serta (Maysitha et al., 2021).

$\mathrm{H}_{4}$ : IOS berpengaruh positif dan signifikan terhadap kualitas laba

\section{Dividend Payout Ratio (DPR)}

Perusahaan yang mendistribusikan dividen mengindikasikan bahwa perusahaan tersebut mempunyai kualitas laba yang lebih baik karena dividen dianggap sebagai sinyal dari manajer kepada seluruh pemegang saham untuk menunjukkan kinerja perusahaan (Fitriani \& Syafruddin, 2015). Dengan konsistennya perusahaan dalam membagikan dividen kepada investor, mengindikasikan kualitas laba yang dimiliki perusahaan tersebut adalah baik. Pendapat tersebut sejalan dengan penelitian (MR \& Sukarmanto, 2021) dan (Fauziah \& Kusumadewi, 2019) dengan hasil penelitian
DPR berpengaruh positif signifikan terhadap kualitas laba.

$\mathrm{H}_{5}$ : DPR berpengaruh positif signifikan terhadap kualitas laba

\section{METODE}

Data dalam penelitian ini merupakan data kuantitatif dengan objek penelitian adalah Perusahaan Indeks LQ 45 Periode 2015-2019. Untuk memperoleh data, peneliti mengunjungi website Bursa Efek Indonesia. Data dianalisis dengan menggunakan pengujian asumsi klasik dan juga pengujian hipotesis. Pada Tabel 1 disajikan daftar populasi dan proses seleksi sampel yang digunakan dalam penelitian ini.

Tabel 1 Proses Seleksi Sampel

\begin{tabular}{|l|c|}
\hline \multicolumn{1}{|c|}{ Keterangan } & $\begin{array}{c}\text { Jumlah } \\
\text { Perusahaan }\end{array}$ \\
\hline $\begin{array}{l}\text { Perusahaan yang terdaftar di LQ 45 } \\
\text { Periode 31 des 2020 }\end{array}$ & 45 \\
\hline $\begin{array}{l}\text { Perusahaan yang tidak konsisten } \\
\text { masuk di LQ 45 Periode 2015 - 2019 }\end{array}$ & $(18)$ \\
\hline $\begin{array}{l}\text { Perusahaan yang masuk Sub Sektor } \\
\text { Perbankan }\end{array}$ & $(5)$ \\
\hline Perusahaan yang mengalami kerugian & $(1)$ \\
\hline $\begin{array}{l}\text { Perusahaan yang tidak membagikan } \\
\text { deviden }\end{array}$ & $(3)$ \\
\hline Jumlah Perusahaan & 18 \\
\hline
\end{tabular}

Sumber: Pengolahan data 2021

Berdasarkan Tabel 1 diperoleh sampel dalam penelitian ini berjumlah 18 perusahaan dengan periode penelitian sebanyak 5 tahun sehingga diperoleh jumlah observasi sebanyak 90.

\section{HASIL DAN PEMBAHASAN Uji Asumsi Klasik}

Hasil uji asumsi klasik yang pertama diperoleh bahwa data tidak berdistribusi normal oleh sebab itu dilakukan transformasi data sehingga data observasi menjadi 87. Berikut hasil pengujian asumsi klasik setelah proses transformasi. 
Uji Normalitas

Tabel 2 Hasil Uji Normalitas

\begin{tabular}{|c|c|c|}
\hline & $\begin{array}{c}\text { Unstandardized } \\
\text { Residual }\end{array}$ \\
\hline \multicolumn{2}{|l|}{$\mathrm{N}$} & 87 \\
\hline Normal & Mean & .0000000 \\
\hline \multirow[t]{2}{*}{ Parameters ${ }^{\mathrm{a}, \mathrm{b}}$} & Std. & .44229333 \\
\hline & Deviation & \\
\hline Most Extreme & Absolute & .112 \\
\hline \multirow[t]{2}{*}{ Differences } & Positive & .061 \\
\hline & Negative & -.112 \\
\hline \multicolumn{2}{|c|}{ Kolmogorov-Smirnov Z } & 1.048 \\
\hline \multicolumn{2}{|c|}{ Asymp. Sig. (2-tailed) } & .222 \\
\hline
\end{tabular}

Sumber : Pengolahan data 2021 (SPSS 21)

Hasil Uji Normalitas menunjukkan bahwa nilai dari Asymp. Sig (2-tailed) di atas 0,05 yakni sebesar 0,222, sehingga disimpulkan data telah terdistribusi secara normal.

\section{Uji Multikolinearitas}

Tabel 3 Hasil Uji Multikolinearitas

\begin{tabular}{|ll|r|r|}
\hline \multirow{2}{*}{ Model } & & \multicolumn{2}{|c|}{ Collinearity Statistics } \\
\cline { 3 - 4 } & & Tolerance & \multicolumn{1}{c|}{ VIF } \\
\hline & (Constant) & & \\
& LN_CR & .769 & 1.300 \\
& LN_SIZE & .299 & 3.345 \\
& LN_DAR & .863 & 1.159 \\
& LN_IOS & .491 & 2.037 \\
& LN_DPR & .373 & 2.684 \\
\hline
\end{tabular}

Sumber : Pengolahan data 2021 (SPSS 21)

Hasil pada Tabel 3 menunjukkan bahwa nilai TOL variabel CR, SIZE, DAR, IOS dan DPR lebih besar dari 0,10 dan nilai VIF lebih kecil dari 10 artinya data terbebas dari gejala multikolinearitas.

Uji Autokorelasi

Tabel 4 Hasil Uji Autokorelasi

\begin{tabular}{|c|c|c|c|c|c|c|}
\hline \multirow[b]{2}{*}{ Model } & \multicolumn{5}{|c|}{ Change Statistics } & \multirow[b]{2}{*}{$\begin{array}{l}\text { Durbin- } \\
\text { Watson }\end{array}$} \\
\hline & $\begin{array}{c}\mathrm{R} \\
\text { Square } \\
\text { Change }\end{array}$ & $\begin{array}{c}\mathrm{F} \\
\text { Change }\end{array}$ & df1 & df 2 & $\begin{array}{l}\text { Sig. F } \\
\text { Change }\end{array}$ & \\
\hline 1 & .277 & 6.208 & 5 & 81 & .000 & 1.982 \\
\hline
\end{tabular}

Sumber : Pengolahan data 2021 (SPSS 21)

Hasil pada Tabel 4 menunjukkan bahwa nilai durbin Watson $=1,982$ dimana nilai $\mathrm{dL}$ Copyright (C) 2021, FINANCIAL: Jurnal Akuntansi sebesar 1,5322 dan dU sebesar 1,7745 sehingga dapat dinyatakan bahwa dU $<$ DW $<4-$ dU atau 1,7745 < 1,982 < 2,2255, yang artinya tanpa kesimpulan.

Uji Heteroskedastisitas

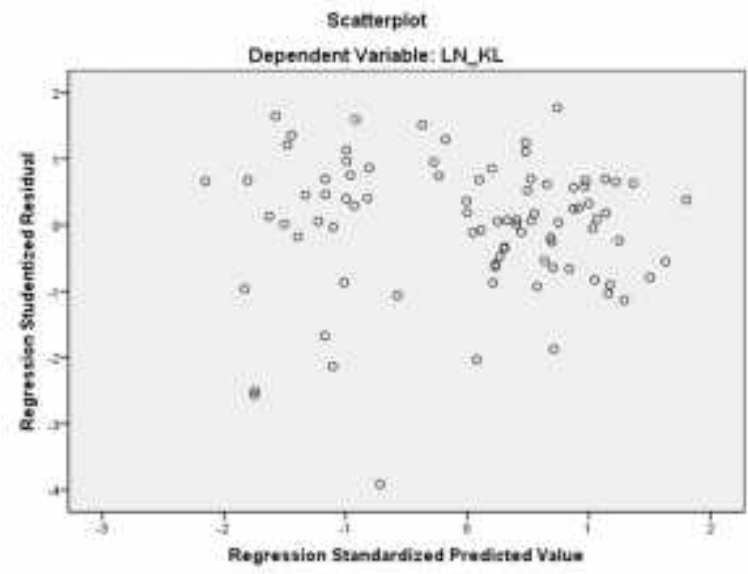

Gambar 1 Hasil Uji Heteroskedastisitas Sumber : Pengolahan data 2021 (SPSS 21)

Dari Gambar 1 dapat disimpulkan tidak terdapat indikasi heteroskedastisitas dikarenakan sebaran data berdistribusi acak dan tidak membentuk pola. Berdasarkan hasil uji asumsi klasik disimpulkan bahwa data terbebas dari gangguan, sehingga penelitian dapat dilanjutkan dengan uji regresi linier berganda.

\section{Uji Hipotesis}

Analisis Regresi Linier Berganda

Tabel 5 Hasil Regresi Linier Berganda

\begin{tabular}{|c|c|c|}
\hline \multirow[b]{2}{*}{ Model } & \multicolumn{2}{|c|}{ Unstandardized Coefficients } \\
\hline & B & Std. Error \\
\hline 1 (Constant) & -23.880 & 5.612 \\
\hline LN_CR & .277 & .101 \\
\hline LN_SIZE & 6.851 & 1.626 \\
\hline LN_DAR & -.039 & .040 \\
\hline LN_IOS & .136 & .068 \\
\hline LN_DPR & .222 & .047 \\
\hline
\end{tabular}

Sumber : Pengolahan data 2021 (SPSS 21)

Berdasarkan Tabel 5 maka dapat dibentuk model persamaan sebagai berikut: 


$$
\begin{gathered}
\text { Y = -23,880 - 0,277LN_CR + } \\
\text { 6,851LN_SIZE - 0,039LN_DAR + } \\
\text { 0,136LN_IOS + 0,222LN_DPR }
\end{gathered}
$$

Dari model persamaan tersebut maka dapat disimpulkan bahwa CR, SIZE, IOS dan DPR memiliki pengaruh yang positif terhadap Kualitas Laba sedangkan DAR memiliki pengaruh negatif Terhadap Kualitas Laba.

Koefisien Korelasi dan Koefisien Determinasi

Tabel 6 Hasil Koefisien Korelasi dan Koefisien Determinasi

\begin{tabular}{|l|c|c|c|c|}
\hline Model & $\mathrm{R}$ & $\begin{array}{c}\mathrm{R} \\
\text { Square }\end{array}$ & $\begin{array}{c}\text { Adjusted R } \\
\text { Square }\end{array}$ & $\begin{array}{c}\text { Std. Error of the } \\
\text { Estimate }\end{array}$ \\
\hline 1 & $.526^{\mathrm{a}}$ & .277 & .232 & .45574 \\
\hline
\end{tabular}

Sumber : Pengolahan data 2021 (SPSS 21)

Dari Tabel 6 memberikan informasi bahwa nilai $\mathrm{r}$ sebesar 0,526 yang artinya kualitas laba memiliki hubungan sedang dengan CR, SIZE, DAR, IOS dan DPR. Sedangkan nilai koefisien determinasi sebesar 0,277 yang artinya variabel CR, SIZE, DAR, IOS dan DPR memiliki pengaruh sebesar $27,7 \%$ terhadap kualitas laba sedangkan variabel lain yang tidak diteliti mempengaruhi kualitas laba sebesar $72,3 \%$.

\begin{tabular}{|c|c|c|c|c|c|}
\hline Model & $\begin{array}{l}\text { Sum of } \\
\text { Squares }\end{array}$ & df & $\begin{array}{l}\text { Mean } \\
\text { Square }\end{array}$ & $\mathrm{F}$ & Sig. \\
\hline 1 Regression & 6.447 & 5 & 1.289 & 6.208 & $.000^{\mathrm{a}}$ \\
\hline Residual & 16.824 & 81 & .208 & & \\
\hline Total & 23.271 & 86 & & & \\
\hline
\end{tabular}

Uji Simultan atau Uji F

\section{Tabel 7 Hasil Uji F}

a. Predictors: (Constant), LN_DPR, LN_DAR, LN_CR,

LN_IOS, LN_SIZE

b. Dependent Variable: LN_KL

Sumber : Pengolahan data 2021 (SPSS 21)

Hasil Tabel 7 menunjukkan bahwa $\mathrm{F}$ hitung memiliki nilai signifikansi lebih kecil Copyright (C) 2021, FINANCIAL: Jurnal Akuntansi dari 0,05 atau dapat dinyatakan $0,000<0,05$, sehingga dapat diambil kesimpulan bahwa secara simultan CR, SIZE, DAR, IOS dan DPR memiliki pengaruh signifikan terhadap Kualitas Laba.

Uji Parsial atau Uji t

Tabel 8 Hasil Uji t

\begin{tabular}{|ll|r|r|}
\hline & & & \\
\hline \multicolumn{1}{|l|}{ Model } & $\mathrm{t}$ & \multicolumn{1}{c|}{ Sig. } \\
\hline $1 \quad$ (Constant) & -4.255 & .000 \\
& LN_CR & 2.755 & .007 \\
& LN_SIZE & 4.213 & .000 \\
LN_DAR & -.972 & .334 \\
LN_IOS & 1.993 & .050 \\
LN_DPR & 4.718 & .000 \\
\hline
\end{tabular}

Sumber : Pengolahan data 2021 (SPSS 21)

Dari Tabel 8 maka dapat dijelaskan bahwa

a. Pengaruh CR terhadap Kualitas laba

Nilai signifikansi dari variabel CR lebih kecil dari 0,05 yaitu sebesar 0,007, sehingga dapat dinyatakan CR memiliki pengaruh positif signifikan terhadap kualitas laba dengan demikian $\mathrm{H}_{1}$ diterima yang berarti bahwa $\mathrm{CR}$ berpengaruh positif signifikan terhadap Kualitas Laba hal ini sejalan dengan penelitian yang dilakukan oleh (Herninta \& Ginting, 2020) dan (Sukmawati et al., 2014). Kondisi ini menandakan bahwa perusahaan memiliki kemampuan untuk memenuhi segala kewajibannya yang segera jatuh tempo yang mengindikasikan bahwa kualitas laba yang dimiliki perusahaan tersebut baik sehingga hal ini menjadi daya tarik investor dalam berinvestasi di perusahaan.

b. Pengaruh Size terhadap Kualitas Laba Nilai signifikansi dari variabel Size berada di bawah 0,05 yaitu sebesar 0,000 , yang artinya Size memiliki pengaruh positif signifikan terhadap kualitas laba dengan demikian $\mathrm{H}_{2}$ diterima. Hal ini 
sejalan dengan penelitian yang dilakukan oleh (Sukmawati et al., 2014) dan (Herninta \& Ginting, 2020) Perusahaan dengan ukuran atau size yang besar akan mendorong adanya peningkatan kualitas laba.

c. Pengaruh DAR Terhadap kualitas laba DAR memiliki nilai koefisien regresi negatif dan nilai signifikansinya berada di atas 0,05 yaitu sebesar 0,334 , sehingga dapat dinyatakan bahwa DAR memiliki pengaruh negatif tidak signifikan terhadap kualitas laba, yang artinya $\mathrm{H}_{3}$ ditolak. Hal ini sejalan dengan penelitian yang dilakukan (Maysitha et al., 2021) dan (Laoli \& Herawaty, 2019). Tingkat hutang yang tinggi pada perusahaan akan memberikan pengaruh yang tinggi pula terhadap risiko keuangan, dan besar kemungkinan perusahaan tidak mampu melunasi seluruh hutangnya. Akibatnya, perusahaan harus mengeluarkan banyak biaya sehingga laba yang dihasilkan rendah kualitasnya. Pada akhirnya pihak manajemen perusahaan akan cenderung melakukan praktik manajemen laba, sehingga berdampak pada menurunnya kualitas laba perusahaan.

d. Pengaruh IOS Terhadap Kualitas Laba IOS memiliki nilai signifikansi sama dengan 0,05 , yang artinya IOS memiliki pengaruh positif signifikan terhadap kualitas laba dengan demikian $\mathrm{H}_{4}$ diterima. Hasil ini sejalan dengan hasil penelitian yang dilakukan oleh (Wulansari, 2013), (Warianto \& Rusiti, 2016) serta (Maysitha et al., 2021). Tingkat pertumbuhan perusahaan tercermin dari IOS sehingga mampu meningkatkan kualitas laba perusahaan.

e. Pengaruh DPR Terhadap kualitas laba Nilai signifikansi DPR berada di bawah 0,05 yaitu sebesar 0,000 , sehingga dapat Copyright (C) 2021, FINANCIAL: Jurnal Akuntansi dinyatakan bahwa DPR berpengaruh positif signifikan terhadap kualitas laba dengan demikian $\mathrm{H}_{5}$ diterima. Hal ini sejalan dengan penelitian yang dilakukan oleh (MR \& Sukarmanto, 2021) dan (Fauziah \& Kusumadewi, 2019) Dalam artian bahwa dengan membagikan dividen secara konsisten kepada pihak investor maka hal ini menandakan bahwa perusahaan memiliki kualitas laba yang baik.

\section{SIMPULAN DAN SARAN}

Hasil penelitian menyatakan bahwa perusahaan dengan nilai CR, Size, DAR, IOS dan DPR yang optimal akan mampu menghasilkan kualitas laba yang baik sehingga menjadi daya tarik terhadap investor dalam berinvestasi di perusahaan.

Bagi peneliti selanjutnya disarankan agar dapat menambah variabel lain yang dapat berpengaruh terhadap kualitas laba contohnya Good Corporate Governance (GCG) karena dengan adanya penerapan GCG yang baik akan dapat menghasilkan kualitas laporan keuangan yang bisa diandalkan. Kondisi ini menumbuhkan kepercayaan investor atas kualitas laba perusahaan sehingga respon pasar juga akan meningkat pula.

\section{DAFTAR PUSTAKA}

Fauziah, L., \& Kusumadewi, R. K. A. (2019). ANALISIS PENGARUH DIVIDEN TERHADAP INDIKATOR KUALITAS LABA. Diponegoro Journal of Accounting, 8(2).

Fitriani, D. A. N., \& Syafruddin, M. (2015). Pengaruh Pembayaran Dividen Terhadap Kualitas Laba. Diponegoro Journal of Accounting, 4(2), 64-75.

Ginting, S. (2013). Analisis Faktor-Faktor yang Mempengaruhi Harga Saham pada Perusahaan Manufaktur di Bursa Efek 
Indonesia. Jurnal Wira Ekonomi

Mikroskil: JWEM, 3(2), 61-70.

HELINA, H., \& PERMANASARI, M. (2017). Faktor-faktor yang Mempengaruhi Kualitas Laba pada Perusahaan Publik Manufaktur. Jurnal Bisnis Dan Akuntansi, 19(1a-5), 325334.

Herninta, T., \& Ginting, R. S. B. R. (2020). FAKTOR-FAKTOR YANG MEMPENGARUHI KUALITAS LABA. ESENSI: Jurnal Manajemen Bisnis, 23(2), 155-167.

Laoli, A. N., \& Herawaty, V. (2019). Pengaruh Profitabilitas, Growth, Leverage, Operating Cycle Dan Prudence Terhadap Kualitas Laba Dengan Firm Size Sebagai Variabel Moderasi. Prosiding Seminar Nasional Cendekiawan, 2-39.

Maysitha, M., Masyithoh, S., \& Lahjie, A. A. (2021). Pengaruh investment opportunity set, likuiditas dan leverage terhadap kualitas laba pada perusahaan sub sektor industri barang konsumsi yang terdaftar di bursa efek indonesia. Jurnal Ilmu Akuntansi Mulawarman (JIAM), 5(2).

MR, D. N., \& Sukarmanto, E. (2021). Pengaruh Deviden Terhadap Kualitas Laba. Prosiding Akuntansi SPeSIA, 7(1), 304-306. https://doi.org/http://dx.doi.org/10.2931 3/.v7i1.26317

Samrotun, Y. C. S. (2015). Kebijakan Dividen Dan Faktor-Faktor Yang Mempengaruhinya. Jurnal Paradigma Universitas Islam Batik Surakarta, 13(01), 116095.

Silitonga, H. P., Sembiring, L. D., Azwar, K., Ervina, N., Putri, D. E., Supitriyani, S., Manurung, S., Susanti, E., Grace, E., Moridu, I., Putri, J. A., \& Nainggolan, C. D. (2020). DASAR-DASAR ANALISA LAPORAN KEUANGAN. In A. Sudirman (Ed.), Widina Bhakti Persada Bandung. Widina Bhakti Persada Bandung.

Sukamulja, S. (2017). Pengantar Pemodelan
Keuangan dan Analisis Pasar Modal. Penerbit Andi.

Sukirno. (2015). Kinerja Emiten LQ-45 : Ini Daftar Laba Perusahaan dalam bulan. Bisnis.Com.

https://market.bisnis.com/read/2016050 3/192/543986/kinerja-emiten-lq-45-inidaftar-laba-45-perusahaan-dalam-3bulan

Sukmawati, S., Kusmuriyanto, K., \& Agustina, L. (2014). Pengaruh struktur modal, ukuran perusahaan, likuiditas dan return on asset terhadap kualitas laba. Accounting Analysis Journal, 3(1).

Thertina, M. R. (2019). Laba Emiten LQ45 Semakin Anjlok, Hanya Sektor Finasial yang Berjaya. Katadata.Co.Id. https://katadata.co.id/marthathertina/fina nsial/5e9a4e5554fad/laba-emiten-lq45semakin-anjlok-hanya-sektor-finansialyang-berjaya

Warianto, P., \& Rusiti, C. (2016). Pengaruh ukuran perusahaan, struktur modal, likuiditas dan investment opportunity set (IOS) terhadap kualitas laba pada perusahaan manufaktur yang terdaftar di BEI.

Wulansari, Y. (2013). Pengaruh Investment Opportunity Set, likuiditas dan leverage terhadap kualitas laba pada perusahaan manufaktur yang terdaftar di BEI. Jurnal Akuntansi, 1(2). 